\title{
ANALISIS KINERJA PT PERTAMINA (PERSERO) PASKA HOLDING COMPANY
}

\author{
Sofiati $^{1}$, Ika Septi Kurnia Anggraeni ${ }^{2}$ \\ Fakultas Ekonomi, STIE Widya Wiwaha Yogyakarta ${ }^{1}$, Universitas Nahdatul Ulama Surakarta ${ }^{2}$ \\ sofiatibg@gmail.com ${ }^{1}, \underline{\text { Ikaseptiunus18@gmail.com }}{ }^{2}$
}

\begin{abstract}
This research was conducted to analyze the financial performance of PT Pertamina (Persero) before and after the holding company so that it can be observed the increase or decrease after the Holding Company. The data used are the financial statements of the post-holding company of PT Pertamina before the Holding Company in the JanuaryDecember 2017 and after the Holding Company in the January - December 2018 period. Data analysis using Du Pont System Analysis. The results showed an increase in the financial ratios before the Holding Company and after the Holding Company. This is indicated by the achievment of an increase in the ratio of Return on Investment, Return on Assets, Cash Ratio, Current Ratio , Collection Period, Inventory Turn Over, Total Asset Turn Over, and Total Equety so that the increase can prove that the research hypothesis proposed that after conducting Holding Company is proven to experience efficiency and increase its financial performance.
\end{abstract}

Keywords: Financial Performance, Holding Company, Du Pont System Analysis

\section{PENDAhULUAN}

Ide awal dari pembentukan holding company sebagai pilihan untuk restrukturisasi BUMN adalah untuk optimalisasi manajemen. Jika ada beberapa BUMN bergerak di sektor yang sama melakukan holding company, maka akan ada share support dalam holding group tersebut, human capital, distribution, information communication and technology) dan sebagainya. Pembentukan holding tersebut akan meningkatkan fleksibilitas perusahaan, anak perusahaan akan bergerak sebagai pure corporate. Pembentukan holding company ini berbeda dengan perusahaan induk yang sudah berdiri dan membentuk anak-anak perusahaan untuk menunjang aktivitasnya. Menurut Widianto ( 2016 ) pengalihan saham dari Perusahaan Gas Negara (PGN) terealisasi dengan adanya Rapat Umum Pemegang Saham Luar Biasa PT Perusahaan Gas Negara (Persero) Tbk. Agenda tersebut merupakan persetujuan perubahan anggaran dasar dan persetujuan pemegang saham atas pengalihan PT PGN ke PT Pertamina. Tim implementasi perusahaan induk BUMN di sektor migas sudah dibentuk, yaitu tim visi dan misi, transaksi, operasional, komunikasi dan sumber daya manusia. Tujuan pembentukan perusahaan induk BUMN di sektor migas adalah meningkatkan efisiensi dan kinerja keuangan. September 2017 pada kuartal III PT Pertamina ( persero) mencatatkan laba bersih US\$1,99 miliar atau RP 26,8 Triliun (Kurs Rp 13.500/US\$). Laba kuartal III tahun 2017 mengalami penurunan sekitar 27\% dibandingkan laba kuartal III tahun 2016, yaitu sebesar US\$ 2, 83 miliar. Penurunan laba tersebut akibat dari dampak kenaikan harga minyak sebesar $30 \%$.

Berdasarkan penjelasan latar belakang di atas maka permasalahannya adalah apakah kinerja keuangan PT Pertamina periode 2017-2018 menjadi lebih efisien paska dibentuknya 
Holding Company. Kim (2016) dalam penelitiannya melakukan analisis kinerja perusahaanperusahaan di Korea, khususnya di industri distribusi makanan. Penelitian ini menganalisis Return On Asset (ROA), Return On Equity (ROE) dan Du Pont Analysis. Hasil penelitian menunjukkan bahwa rata-rata perusahaan di Industri distribusi makanan di Korea menunjukkan kinerja keuangan yang semakin meningkat. Penelitian Doorasamy (2016) untuk mengukur kinerja keuangan dengan menggunakan Dupont System analyisis . Hasil temuan (Elita et al., 2015) kinerja keuangan PT Semen Gresik selama periode 2009-2013 cenderung mengalami penurunan. Dari hasil penelitian-penelitian tersebut menunjukkan bahwa rata-rata kinerja keuangan perusahaan yang melakukan holding cenderung meningkat sehingga hipotesis penelitian yang diajukan adalah diduga setelah melakukan holding PT Pertamina terbukti mengalami efisiensi dan peningkatan kinerja keuangannya. Penelitian ini berbeda dengan penelitian sebelumnya tentang obyek dan alat analisisnya. Penelitian ini bertujuan untuk menganalisis efisiensi kinerja keuangan PT Pertamina periode 2018 paska Holding Company.

\section{KAJIAN LITERATUR}

Seperti dikemukakan Solarz (1992) dalam Gajewski (2013) bahwa holding company sebagai perusahaan yang memiliki saham perusahaan lain dalam jumlah cukup untuk mempengaruhi keputusan perusahaan tersebut. Adapun Kubot (1993), Stecki (1999), Nogalski \& Ronkowski (1994) dalam Gajewski (2013) holding company adalah perusahaan induk sebagai kelompok perusahaan yang memiliki kemampuan untuk memaksakan kehendaknya dengan memegang saham yang cukup dalam satu perusahaan. Konsep holding menurut Szumański (1996) dalam Gajewski (2013) adalah gagasan interdisipliner yang belum didefinisikan dalam sistem hukum manapun di dunia. Menurut Kessler (1996) dalam Gajewski (2013) ada tiga kriteria untuk menentukan apakah sebuah struktur digolongkan sebagai holding company: pertama, Penyusunan neraca konsolidasi, yang mencakup laporan hasil keuangan perusahaan induk dan anak perusahaan; kedua, memiliki mayoritas suara pada rapat umum pemegang saham; ketiga, rasio hubungan dengan manajemen perusahaan, yang tergantung pada keputusan entitas induk.

Ada banyak alasan untuk mendirikan holding company. Salah satu alasan terpenting adalah pengembangan perusahaan. Menurut Haus, Berry \& Karas (1993) dalam Gajewski (2013) salah satu cara yang populer untuk memecahkan masalah ini adalah memisahkan berbagai komponen perusahaan (anak perusahaan, cabang, pabrik) menjadi entitas ekonomi independen dan menciptakan struktur holding. Egger \& Merlo (2011) dalam Gajewski (2013) alasan penting untuk mendirikan holding company adalah kemampuan untuk menggunakan struktur holding sebagai metode untuk memperbesar perusahaan. Pembentukan struktur holding yang melibatkan modal di entitas lain menyebabkan peningkatan pesat pada potensi ekonomi bagi perusahaan. Alasan penting lainnya untuk mendirikan holding company adalah mengubah profil bisnis sambil menghindari risiko potensi kegagalan usaha baru oleh entitas yang telah menjalankan bisnis yang menguntungkan.

Kinerja keuangan merupakan gambaran kondisi keuangan perusahaan pada periode tertentu baik menyangkut aspek penghimpunan dana maupun penyaluran dana yang biasanya diukur dengan indikator rasio keuangan (Sartono, 2012: 113-115). Menurut Weston (2009:215) kinerja keuangan adalah kemampuan perusahaan untuk mempertahankan dan memperbaiki keuangan perusahaan, sehingga tidak mengarahkan perusahaan kepada risiko keuangan yang lebih besar. Dalam melakukan analisis kinerja keuangan manajer keuangan dapat 
membandingkan rasio atau prestasi keuangan satu periode perusahaan dibandingkan rata-rata rasio industrinya. Kinerja keuangan merupakan salah satu faktor yang menunjukkan efektifitas dan efisiensi suatu organisasi dalam mencapai tujuan organisasi. Efektifitas apabila manajemen memiliki tujuan yang tepat atau suatu alat yang tepat untuk mencapai tujuan. Efisiensi diartikan sebagai rasio perbandingan antara masukan dan keluaran yaitu dengan masukan terntentu memperoleh keluaran yang optimal. Analisis keuangan yang mencakup analisis rasio keuangan, analisis kelemahan dan kekuatan di bidang finansial akan sangat membantu dalam menilai prestasi manajemen masa lalu dan prospeknya di masa datang. Dengan analisis keuangan ini dapat diketahui kekuatan serta kelemahan yang dimiliki oleh seorang business entreprise. Rasio tersebut dapat memberikan indikasi apakah perusahaan memiliki kas yang cukup untuk memenuhi kewajiban finansialnya, besarnya piutang yang cukup rasional, efisiensi manajemen persediaan, perencanaan pengeluaran investasi yang baik, dan struktur modal yang sehat sehingga tujuan memaksimumkan kemakmuran pemegang saham dapat dicapai. Kinerja keuangan yang diukur antara lain profitabilitas, efisiensi, pertumbuhan ekonomi, full employment, dan equity. Profitabilitas merupakan kemampuan suatu perusahaan/industri untuk menghasilkan keuntungan dari keseluruhan modal yang digunakan. Ukuran untuk mengetahui tingkat keuntungan diantaranya adalah return on assets, return on equity, return on investment , pricelearning ratio.

\section{Penelitian Terdahulu dan Pengembangan Hipotesis}

Gajewski (2013) menemukan hasil penelitiannya bahwa dalam perekonomian Polandia, rata-rata perusahaan yang melakukan holding secara umum aktivitasnya meningkat. Ficbauer dan Rezbakova (2014) daam temuannya menggunakan metode kuesioner dan analisis rasio keuanga menginvestigasi terhadap 15 perusahaan yang melakukan holding mengalami kenaikan dalam cash flow management. Minton, Taillard dan Wiliamson (2012) melakukan penelitian mengenai kinerja keuangan pada industri perbankan yang melakukan holding, hasil penelitian menunjukkan adanya profil risiko yang semakin meningkat dan kinerja saham yang semakin buruk pada industri perbankan saat terjadi krisis keuangan di USA. Di samping itu penelitian ini juga menyebutkan adanya hubungan antara kemampuan direksi dalam pengambilan keputusan dan tingkat risiko perbankan. Putranto (2009) melakukan penelitian mengenai analisis model holding pada PT Rajawali Nusantara Indonesia (Persero). PT RNI telah melakukan investment holding company, hal ini dilakukan agar terdapat pemilahan tugas yang jelas antara induk perusahaan dan anak perusahaan. Hasil penelitian ini menemukan bahwa kinerja korporasi cenderung menurun terus menerus. Novitasari (2016) menemukan hasil penelitiannya di PT Pelindo I Medan bahwa tingkat Return on Investment (ROI), Net Profit Margin (NPM), dan Total Asset Turn Over (TATO) periode tahun 2012-2014 meningkat. Rizal

2016 menemukan bahwa PT Garuda Indonesia Tbk periode tahun 2011-1015 rasio likuiditas,rasio solvabilitas, dan rasio profitabilitas kurang baik.

Harahap (2004) dalam Phrasasty, Kertahadi dan Azizah (2015) menyebutkan bahwa kelemahan Du Pont System adalah dengan menggunakan ROI saja tidak akan dapat digunakan untuk melakukan perbandingan antara dua permasalahan atau lebih dengan mendapatkan kesimpulan yang memuaskan. Penelitian yang dilakukan oleh Phrasasty, Kertahadi dan Azizah (2015) yaitu melakukan analisis kinerja pada PT Semen Gresik yang melakukan holding, selama periode 2009 - 2013 kinerja keuangan PT Semen Gresik menunjukkan peningkatam. Hal tersebut dapat dilihat dari pergerakan kurva trend analysis. Sedangkan saat menggunakan Du Pont System Analysis kinerja keuangan PT Semen Gresik selama periode 2009-2013 
cenderung mengalami penurunan. Hal tersebut dapat dilihat dari tingkat ROE yang fluktuatif selama lima tahun. ROE yang fluktuatif tersebut diakibatkan oleh beberapa hal antara lain: adanya inefisiensi pada total cost yang meningkat tetapi tidak diimbangi oleh peningkatan EAT sehingga mengakibatkan NPM mengalami fluktuasi selama lima tahun. Hasil penelitian tersebut juga menunjukkan adanya keadaan TATO yang fluktuatif akibat adanya total aset yang meningkat tetapi tidak diimbangi dengan nilai sales. Kondisi NPM dan TATO yang fluktuatif ini mengakibatkan nilai ROI semakin menurun. Kondisi ROI yang semakin menurun juga berimbas pada angka ROE karena kondisi inefisiensi total aset tidak diimbangi dengan naiknya pendapatan modal. Berdasarkan hasil penelitian tersebut maka hipotesis penelitian yang diajukan adalah setelah melakukan holding perusahaan induk diduga akan mengalami efisiensi atau peningkatan pada kinerja keuangan perusahaan. Paska holding perusahaan diduga akan mengalami peningkatan pada ROI dan ROE jika perusahaan tersebut mengalami efisiensi kinerja keuangan

\section{METODE}

Data yang dipakai pada penelitian ini adalah data sekunder. Data sekunder mengacu pada informasi yang diperoleh dari tangan kedua oleh peneliti yang berkaitan dengan variabel (Sekaran, 2006). Data sekunder yang digunakan adalah laporan keuangan PT Pertamina periode 2017 hingga Desember 2018 antara lain laporan laba rugi perusahaan dan neraca tahunan perusahaan. Selain itu penelitian ini menggunakan data dividen dan harga saham perusahaan serta tingkat suku bunga bulanan sertifikat bank indonesia periode 2017 dan 2018.

Rasio keuangan yang digunakan dalam metode Du Pont System (Sartono,2012) meliputi : Rasio Profitabilitas (Net Profit Margin), Rasio Aktivitas (Total Assets Turn Over), Perhitungan metode Dupont System meliputi Return on Investmen (ROI) dan Return on Equity (ROE) dengan Debt Ratio dan Multiplier Equity. Teknik analisis kinerja keuangan dengan menggunakan metode Du Pont System (Sartono,2012). Adapun langkah- langkah yang dilakukan adalah mengitung rasio - rasio keuangan yaitu Rasio Likuiditas dengan menghitung NWC (Net working Capital), CR (Current Ratio) dan QR (quick Ratio).

Rumus untuk menghitung NWC adalah sebagai berikut:

NWC $=$ Aktiva Lancar - Hutang Lancar

Rumus untuk menghitung Current ratio adalah sebagai berikut:

$\mathrm{CR}=\frac{\text { Aktiva Lancar }}{\text { Hutang Lancar }} \times 100 \%$

Rumus untuk menghitung Quick Ratio adalah sebagai berikut:

$$
\mathrm{QR}=\frac{\text { Aktiva Lancar-Persediaan }}{\text { Hutang Lancar }} \times 100 \%
$$

Ratio Aktivitas dengan menghitung ITO, AAI,FATO dan TATO

Rumus untuk menghitung ITO (Inventory Turnover ratio)

ITO $=\frac{\text { Harga Pokok Penjualan }}{\text { Rata-rata Persediaan }} \times 1$ kali

Rumus untuk menghitung AAI (Average Age of Inventory) 
$\mathrm{AAI}=\frac{360}{\text { Inventory Turnover }}$

Rumus untuk menghitung FATO (Fixed Asset Turnover)

FATO $=\frac{\text { Penjualan }}{\text { Aktiva } \text { Tetap }} \times 1$ kali

Rumus untuk menghitung TATO (Total Asset turnover)

TATO $=\frac{\text { Penjualan }}{\text { Total Aktiva }} \times 1$ kali

Menghitung Ratio Solvabilitas

Menghitung DR (Debt Ratio)

$\mathrm{DR}=\frac{\text { Total Hutang }}{\text { Total Aktiva }} \times 100 \%$

Menghitung Debt Equity Ratio

DER $=\frac{\text { Hutang Jangka Panjang }}{\text { Modal Sendiri } x} \times 100 \%$

Menghitung DTCR (Debt to Total Capitalization Ratio

$\mathrm{DTCR}=\frac{\text { Hutang Jangka Panjang }}{\text { Hutang Jangka Panjang }+ \text { Modal Sendiri }} \times 100 \%$

. Menghitung Rasio Profitabilitas

Menghitung Gross Profit Margin

$\mathrm{GPM}=\frac{\text { Penjualan }-H P P}{\text { Penjualan }} \times 100 \%$

Menghitung OPM (Operating Profit Margin)

$\mathrm{OPM}=\frac{\text { Laba Operasi }}{\text { Penjualan }} \times 100 \%$

Menghitung NPM (Net Profit Margin)

$\mathrm{NPM}=\frac{\text { Laba bersih sesudah pajak }}{\text { Penjualan }} \times 100 \%$

Setelah menghitung rasio-rasio tersebut kemudian peneliti melakukan analisis dengan menggunakan Du Pont System dengan langkah sebagai berikut:

Menghitung Return On Investment yaitu ROI = NPM x TATO x 100\%. Jika nilai ROI menunjukkan kenaikan merupakan indikator bahwa kemampuan manajemen perusahaan mengalami kenaikan dalam melakukan pengelolaan harta atau asset untuk menghasilkan laba operasi demikian sebaliknya jika ROI mengalami penurunan, hal ini merupakan indikator bahwa kemampuan manajemen mengalami penurunan dalam melakukan pengelolaan harta atau asset untuk menghasilkan laba operasi.

Menghitung ROE (Return On Equity)

$\mathrm{ROE}=\frac{\text { Return On Investment }}{1-\text { Debt ratio }} \times 100 \%$ 
Jika nilai ROE mengalami kenaikan hal ini merupakan indikator bahwa tingkat penghasilan bersih yang diperoleh perusahaan atau modal yang diinvestasikan mengalami kenaikan, demikian sebaiknya jika ROE mengalami penurunan, hal ini menunjukkan indikator bahwa penghasilan bersih yang diperoleh perusahaan mengalami penurunan

\section{HASIL DAN DISKUSI \\ Pembahasan}

Penelitian ini dilakukan untuk menganalisis kinerja keuangan PT Pertamina (Persero) paska dilakukannya holding periode 2017 - 2018. Untuk membuktikan hipotesis pertama yang menyatakan bahwa setelah melakukan holding perusahaan induk diduga mengalami efisiensi sehingga kinerja keuangan meningkat maka digunakan metode DuPont Analysis (Sartono,2012). Data pembanding kinerja keuangan sebelum dan paska Holding Company PT Pertamina (Persero) disajikan dalam tabel 1 berikut:

Tabel.1

Kinerja Keuangan PT Pertamina (Persero)

Per 31 Desember 2018 (dalam \%)

\begin{tabular}{|l|l|l|}
\hline Kinerja Keuangan & $\begin{array}{l}\text { Paska HoldingCompany } \\
\text { 31 -12- 2018 }\end{array}$ & $\begin{array}{l}\text { Sebelum HoldingCompany } \\
\mathbf{3 1 - 1 2}-\mathbf{2 0 1 7}\end{array}$ \\
\hline ROE & 13,21 & 11,13 \\
\hline ROI & 15,66 & 5,37 \\
\hline CASH RATIO & 66,83 & 22,60 \\
\hline CURRENT RATIO & 165,71 & 4,46 \\
\hline $\begin{array}{l}\text { COLLECTION } \\
\text { PERIODE(hari) }\end{array}$ & 50 & 2 \\
\hline ITO (hari) & 40 & 20 \\
\hline TATO & 99,23 & 12,16 \\
\hline TMS & 40,31 & 4,69 \\
\hline
\end{tabular}

Sumber: Laporan Keuangan ,diolah 2019

Berdasarkan pembandingan kinerja keuangan sebelum dan paska Holding Company maka hasilnya ditunjukkan dalam model Du Pont Analysis pada gamba1.dan 2 berikut: 


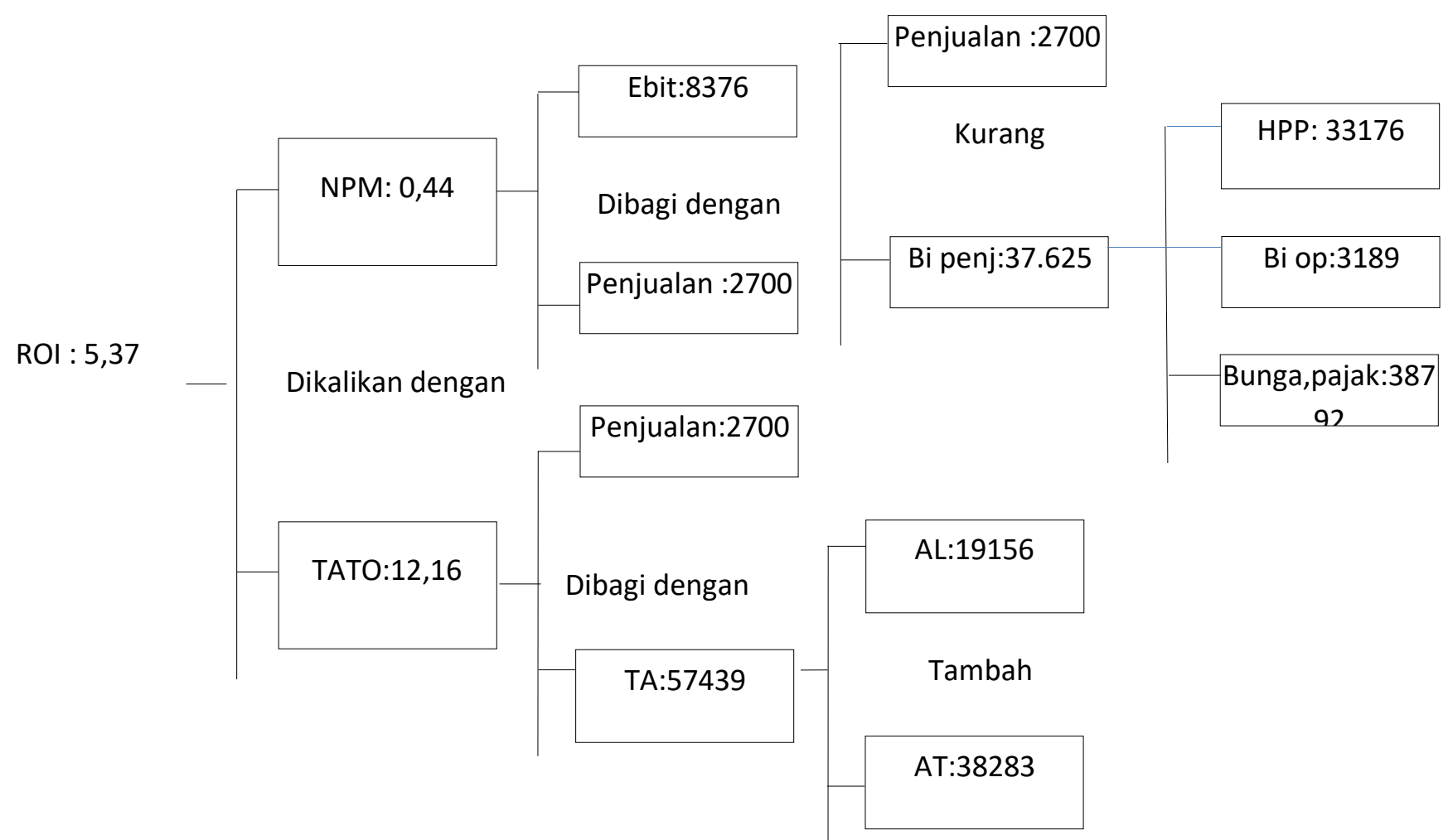

Gambar .1.Model Du Pont Analysis PT Pertamina Sebelum Holding Company 2017 Sumber : data diolah 2019

ROI: 15,66

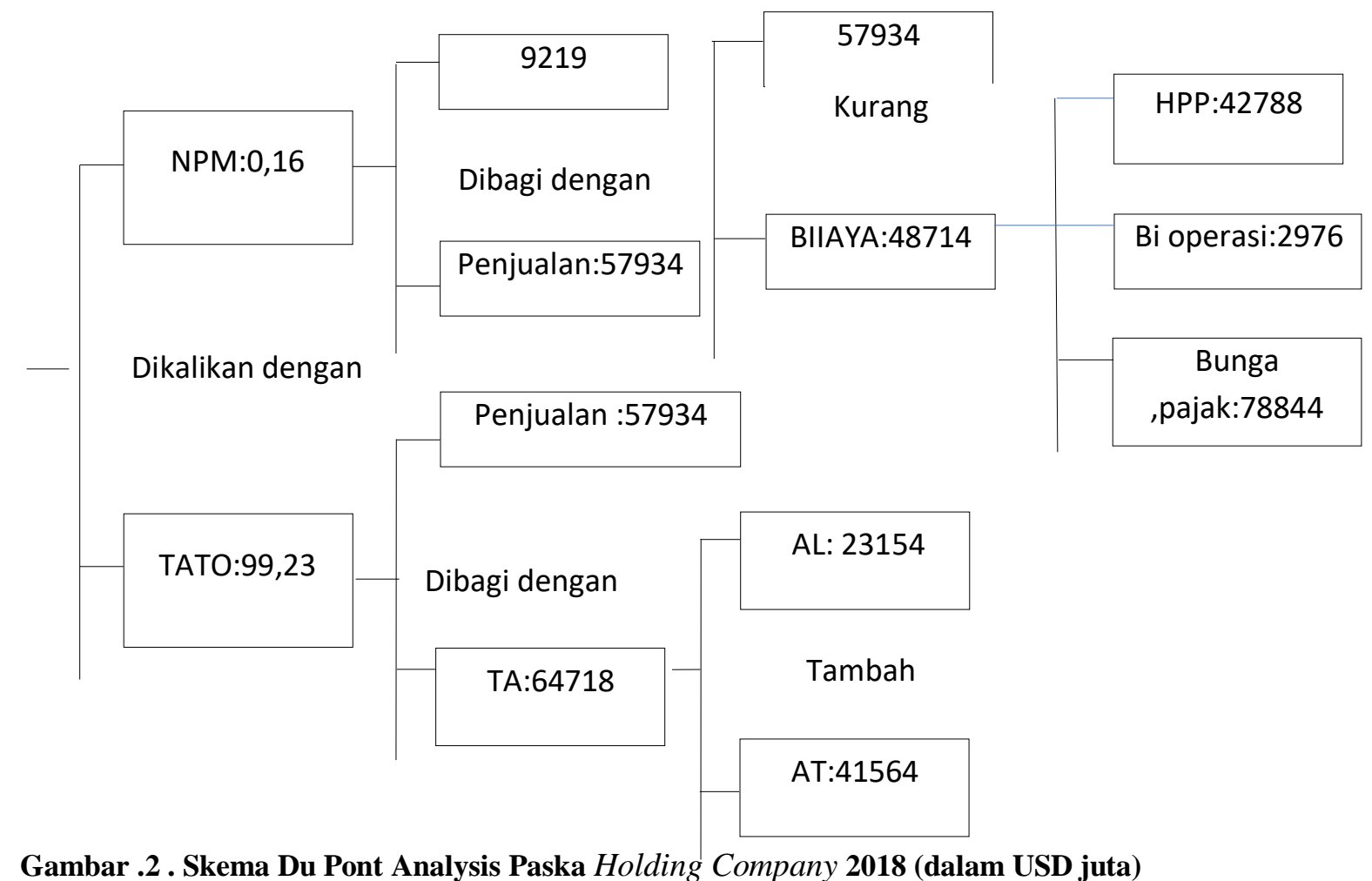


Sumber : data diolah,2019

Dari skema pada gambar Du Pont dapat dirangkum dalam tabel .2. berikut:

Tabel.2

KINERJA KEUANGAN PT PERTAMINA (PERSERO)

PER 31 DESEMBER 2018 (dalam \%)

\begin{tabular}{|l|l|l|}
\hline Kinerja Keuangan & $\begin{array}{l}\text { Paska holding company } \\
\mathbf{3 1} \mathbf{- 1 2}-\mathbf{2 0 1 8}\end{array}$ & $\begin{array}{l}\text { Sebelum Holding Company } \\
\mathbf{3 1 - 1 2}-\mathbf{2 0 1 7}\end{array}$ \\
\hline ROE & 13,21 & 11,13 \\
\hline ROI & 15,66 & 5,37 \\
\hline CASH RATIO & 66,83 & 22,60 \\
\hline CURRENT RATIO & 165,71 & 4,46 \\
\hline $\begin{array}{l}\text { COLLECTION } \\
\text { PERIODE(hari) }\end{array}$ & 50 & 2 \\
\hline ITO (hari) & 40 & 20 \\
\hline TATO & 99,23 & 12,16 \\
\hline TMS & 40,31 & 4,69 \\
\hline
\end{tabular}

Sumber: Laporan Keuangan , diolah 2019

Analisis Profitabilitas Terhadap Investasi Sebelum dan Paska Holding Company

Return on Investment (ROI) PT Pertamina pada tahun 2017 mencapai 5,37\%. Adapun tahun 2018 mencapai 15,66 \% diatas RKAP 2018 sebesar 10,29\%. Return on Investment (ROI) sebagai perbandingan antara EBITDA dengan Capital Employed digunakan untuk menganalisis keseimbangan antara laba dengan dana yang telah diinvestasikan untuk kegiatan operasi perusahaan. Kenaikan capaian Return on Investment (ROI) dari tahun 2017 ke tahun 2018 sebesar 10,29\% artinya dari dana yang diinvestasikan sebesar USD 57.439 juta di tahun 2017 dan USD 64.718 juta mampu meningkatkan laba sebesar 10,29\%. Return on Equity (ROE) PT Pertamina tahun 2017 mencapai 11,13 .Adapun di tahun 2018 mencapai 13,21 diatas RKAP sebesar 2,08\%. Return on Equity (ROE) merupakan salah satu profitability ratio yang digunakan untuk mengukur kemampuan perusahaan dalam menghasilkan laba dari investasi pemegang saham di perusahaan. Kenaikan capaian Return on Equity (ROE) dari tahun 2017 ke tahun 2018 sebesar 2,8\% artinya dari dana yang diinvestasikan para pemegang saham sebesar USD 29.610 juta atau naik dari USD 27.349 juta di tahun 2017 mampu meningkatkan laba sebesar $2,8 \%$.

\section{Analisis Perputaran Total Aktiva Sebelum dan Paska Holding Company}

Total Asset Turn Over (TATO) PT Pertamina pada tahun 2018 sebesar 99,23\% lebih tinggi dibandingkan RKAP tahun 2018 sebesar 87,07\% . Total Asset Turn Over (TATO ) merupakan merupakan Activity Ratio untuk menilai efektifitas penggunaan dana yang tertanam dalam jumlah aset dalam rangka menghasilkan pendapatan. Total Asset Turn Over (TATO) dihitung dengan membandingkan total pendapatan dengan Capital Employed. Kenaikan capaian Total Asset Turn Over (TATO) dari tahun 2017 sebesar 12,16\% ke tahun 2018 capaian meningkat $87,07 \%$ artinya dari penggunaan dana yang tertanam dalam aset sebesar USD 64.718 juta atau naik dari USD 57.439 juta di tahun 2017 mampu meningkatkan pendapatan sebesar $87,07 \%$.

\section{Analisis Kolektabilitas Piutang Sebelum dan Paska Holding Company}


Tingkat kolektabilitas piutang Receivable Collection Period (RCP) pada tahun 2018 , PT Pertamina memiliki tingkat koletabilitas piutang sebesar 50 hari, yaitu lebih lama 12 hari dari kolektabilitas tahun 2017. Hal ini terutama disebabkan terdapat peningkatan piutang usaha seiring dengan adanya peningkatan pendapatan.

\section{Analisis Tingkat Perputaran Persediaan Sebelum dan Paska Holding Company}

Inventory Turn Over (ITO) PT Pertamina pada tahun 2018 adalah 40 hari, hal ini lebih cepat 20 hari dibandingkan dengan RKAP 2018 yaitu 60 hari.hal ini terutama dipengaruhi adanya kenaikan nilai perusahaan sebagai akibat kenaikan harga rata - rata ICP dan harga publikasi minyak tahun 2018.

\section{Analisis Total Modal Sendiri Terhadap Total Aktiva Sebelum dan Paska Holding Company}

Total Modal Sendiri (TMS) terhadap Total Aset (TA) PT Pertamina pada tahun 2018 sebesar 40,31\% lebih tinggi RKAP 2018 sebesar 35,63\%. TMS terhadap TA dihitung dengan membandingkan total modal sendiri dengan total aktiva. Total modal sendiri merupakan total ekuitas dikurangi dengan saldo laba yang belum ditentukan penggunaannya.

\section{Analisis Profitabilitas Terhadap Penjualan Sebelum dan Paska Holding Company}

Net Profit Margin (NPM ) merupakan pengukuran tingkat profitabilitas penjualan yang dihasilkan. Tingkat laba bersih PT Pertamina pada tahun 2017 sebesar USD 2700 juta menurun di tahun 2018 sebesar USD 2636 juta. Namun penjualan dan usaha lainnya mengalami peningkatan USD 57.934 juta atau lebih tinggi 25,94\% dibanding pencapaian tahun 2017 sebesar USD 46.000 juta. Pencapaian tahun 2018 tersebut merupakan kontribusi dari :

a. Penjualan minyak, energi panas bumi dan gas sebesar USD 44.743 juta atau $77,23 \%$ dari total penjualan dan pendapatan usaha lainnya.

b. Penggantian biaya subsidi dari pemerintah sebesar USD 5,632 juta atau 9,72\% dari total penjualan dan pendapatan usaha lainnya.

c. Imbalan jasa pemasaran sebesar USD 15 juta atau $0,03 \%$ dari total penjualan dan pendapatan usaha lainnya

d. Penjualan ekspor minyak mentah, gas bumi, dan produk minyak sebesar USD 3.637 juta atau 6,28\% dari total penjualan dan pendapatan usaha lainnya

e. Pendapatan usaha dari aktivitas operasi lainnya sebesar USD 3.906 juta atau 6,7\% dari total penjualan dan pendapatan usaha lainnya. Kenaikan yang sangat signifikan jika dibandingkan tahun 2017 sebesar USD 740 juta, faktor utama penyebab kenaikan tersebut dipengaruhi oleh adanya peraturan presiden tahun 2018 yang menyebabkan penyesuaian penjualan eceran jenis bahan bakar minyak tertentu.

\section{Analisis Biaya - biaya Penjualan Sebelum dan Paska Holding Company}

Pada tahun 2018 biaya pokok penjualan dan biaya langsung lainnya mencapai USD 48.714 juta atau naik sebesar 29,47 \% dari realisasi tahun 2017 yang mencapai 37.625 juta. Biaya - biaya tersebut terdiri dari biaya pokok penjualan, biaya produksi serta biaya operasi yang memiliki kontribusi kenaikan terbesar . Biaya pokok penjualan selama tahun 2018 sebesar USD 42.755 juta atau naik sebesar 28,97\% dari tahun 2017 sebesar USD 33.176 juta. Kenaikan tersebut terutama disebabkan naiknya pembelian bahan baku dan impor produk yang dipengaruhi kenaikan realisasi ICP dan publikasi harga minyak di tahun 2018 dibandingkan dengan tahun sebelumnya.

Analisis Kas Terhadap Aktiva lancar Sebelum dan Paska Holding Company 
Rasio kas (cash ratio) PT Pertamina pada tahun 2018 mencapai 66,83\%, diatas RKAP 2018 sebesar 44,23\%. Rasio kas diperoleh dengan membandingkan kas dan setara kas ditambah dengan investasi jangka pendek dengan liabilitas jangka pendek

\section{Analisis Aktiva lancar Terhadap Utang Lancar Sebelum dan Paska Holding Company}

Current Ratio (CR) PT Pertamina pada tahun 2018 mencapai 165,71 \% , dibawah RKAP 2018 sebesar 170,17 \%. Rasio lancar merupakan salah satu Liquidity Ratio yang digunakan perusahaan untuk mengukur seberapa jauh aset lancar yang dimiliki perusahaan dapat digunakan untuk melunasi liabiliti jangka pendek.

Tercapainya peningkatan rasio Return on Investment, Return On Asset, Cash Ratio, Current Ratio , Collection Period, Inventory Turn Over, Total Asset Turn Over, dan Total Modal Sendiri tersebut berdasarkan Du Pont Analysis dapat mendukung hipotesis penelitian bahwa setelah melakukan holding perusahaan induk terbukti mengalami efisiensi dan peningkatan kinerja keuangannya. Doorasamy (2016), Kim ( 2016) dan Novitasari (2016) bahwa rata- rata capaian ROI dan ROA meningkat. Namun hasil penelitian ini tidak mendukung hasil temuan Minton ( 2012), Putranto (2009), dan Elita et al., (2015) yang ditunjukkan dengan ROE yang fluktuatif dan ROI yang menurun. ROE yang fluktuatif disebabkan adanya pertama, adanya inefisiensi pada penggunaan total cost (TC) yang tinggi namun tidak dimbangi oleh peningkatan EAT sehingga mengakibatkan NPM mengalami fluktuati, kedua., adanya inefisiensi Total Aset sehingga mengakibatkan TATO fluktuatif. Menurut Harahap (2004) bahwa kelemahan Du Pont Analysis adalah dengan menggunakan ROI saja tidak akan dapat digunakan untuk melakukan perbandingan antara dua masalah atau lebih dengan kesimpulan yang memuaskan.

\section{KESIMPULAN}

Berdasarkan analisis kinerja keuangan PT Pertamina (Persero) sebelum dan paska dilakukannya holdimg company, hasil penelitian menunjukkan bahwa dengan metode Du Pont System Analysis terbukti bahwa paska holding perusahaan induk kinerja keuangannya efisien , hal ini dibuktikan dengan tercapainya peningkatan rasio - rasio keuangan periode sebelum Holding Company tahun 2017 dengan paska Holding Company tahun 2018 . Dengan tercapainya peningkatan rasio Return on Investment, Return On Asset, Cash Ratio, Current Ratio , Collection Period, Inventory Turn Over, Total Asset Turn Over, dan Total Modal Sendiri tersebut dapat mendukung hipotesis penelitian bahwa setelah melakukan holding perusahaan induk terbukti mengalami efisiensi dan peningkatan kinerja keuangannya. Hasil penelitian ini mendukung hasil penelitian Doorasamy (2016) bahwa rata- rata capaian ROI dan ROA meningkat, namun hasil penelitian ini tidak sejalan dengan hasil temuan Elita (2015) yang ditunjukkan dengan ROE yang fluktuatif dan ROI yang menurun. Menurut Harahap (2004) bahwa kelemahan Du Pont Analysis adalah dengan menggunakan ROI saja tidak akan dapat digunakan untuk melakukan perbandingan antara dua masalah atau lebih dengan kesimpulan yang memuaskan.

\section{Saran}

Mengingat kelemahan metode DuPont Analysis tersebut maka penelitian yang akan datang metode Economic Value Added (EVA) dan Market Value Added (MVA) digunakan untuk mengukur kinerja keuangan PT Pertamina. Konsep EVA mampu menutupi kekurangan dari analisis rasio keuangan sehingga kedua alat pengukur kinerja keuangan dapat membantu pihak-pihak yang bersangkutan baik pemegang saham maupun perusahaan. Market Value 
Added merupakan kumulatif dari kinerja perusahaan yang dihasilkan dari berbagai investasi yang telah dilakukan maupun yang akan dilakukan. Dengan demikian peningkatan MVA menunjukkan keberhasilan perusahaan dalam memaksimalkan kekayaan para pemegang saham dengan alokasi sumber-sumber yang tepat. Dengan demikian MVA merupakan ukuran kinerja eksternal perusahaan.

\section{REFRENSI}

Anonimous. ( 2018), PT BursaEfek Indonesia :idx.co.id

Doorasamy, Mishelle., (2016). Using DuPont Analysis to Asses The Financial Performance of The Top 3 JSE Listed Companies in The Food Industry.Journal Investment Management and Financial Innovation, Volume 13, Issue 2, 29-43.

Elita., Ika Phrasasty., Kertahadi., dan Devi., Farah Azizah. (2015). Analisis Kinerja Keuangan Dengan Menggunakan DuPont System. Jurnal Administrasi Bisnis (JAB), Vol2, No. 1. Februari.1-10.

Emmy.,Pangaribuan Simanjuntak. (1997) Seri Hukum Dagang, Perusahaan Kelompok (Group Company/Concern). Universtas Gadjah Mada, Yogyakarta, Halaman 7.

Gajewski ,Dominik. ( 2013). The Holding Company as an instrumentof Companies Tax Financial Policy Formation. www.ce.virja.pl, Vol 7, Issue 1, 75-82.

Harahap, Sofyan Syafri. ( 2010). Analisis Kritis Atas Laporan Keuangan . edisi 1 Jakarta, Rajawali Press

Kim , Hak-Seon .(2016). A Study of Financial Performance using DuPont Analysis in Food Distribution Market. Journal Culinary Science and Hospitality Research, Volume 2, Number 6. September.

Minton, Bernadette., Jerome P., Tailard., dan Rohan.,Williamson. ( 2012) . Financial Expertise of the Board, Risk Taking and Perfrormance: Evidence From Bank Holding Companies. JEL Classification. July.1-55.

Noviasari,Tuti .(2016). Analisis DuPont System (Return on Investment, Net Profit Margin, dan Total Asset Turnover) Dalam Mengukur Kinerja Keuangan Pada PT Pelindo I (Persero) .Skripsi Medan,Universitas Sumatra Utara

Putranto,Dwi Purnomo. (2009). Analisis model holding company PT Rajawali Nusantara Indonesia (Persero). Tesis S2. Magister Manajemen Agribisnis UGM

Rizal Mohammad. (2016). Analisis Kinerja Keuangan PT Garuda Indonesia Tbk .Jurnal Serambi Ekonomi dan Bisnis Vol 4 No 1

Sartono, Agus. (2012). Manajemen Keuangan: Teori dan Aplikasi .Edisi 4 BPFE Yogyakarta

Sekaran,Uma.( 2000). Metode Penelitian untuk Bisnis Jilid 2 /Edisi Jakarta Salemba

Widianto, Satrio.2016. Kinerja Positif PT Pertamina Layak Jadi Induk Usaha. Kompas 28 Agustus

Vlachy.(2008). Investigating a Thin - Capitalization Rule: an option-based Analysis,.Politicka Ekonomie,56(5), 656-668

Weston, J. F \& Copeland. E.T.( 2009). Manajemen Keuangan. Edisi 9. Jakarta: Binarupa

Aksara. 